Journal of Qualitative Criminal Justice \& Criminology • 2021 | Volume 10, Issue 1

\title{
Straight From the Source:
} Examining Gender

\section{Differences in Inmate}

\section{Advice for Avoiding Prison Sexual Victimization}

Beatriz Amalfi Marques ${ }^{1}$, Ashley G. Blackburn ${ }^{2}$, Shannon K. Fowler ${ }^{2}$, Janet L. Mullings ${ }^{1}$, Maria L. Lecuna ${ }^{2}$

${ }^{1}$ Sam Houston State University, ${ }^{2}$ University of Houston Downtown

License: Creative Commons Attribution 4.0 International License (CC-BY 4.0). 


\section{ABSTRACT}

Once incarcerated, inmates face a myriad of potential threats to their physical and emotional wellbeing. The threat of being sexually or otherwise victimized while in prison breeds anxiety and fear among inmates, especially those who are new to the prison environment. In response, inmates have developed strategies to avoid victimization. The present study, utilizing self-report questionnaires, asked a sample of male and female inmates in a large Southern prison system about the advice they would give to another newly incarcerated inmate to avoid being sexually assaulted. A thematic analysis of inmates' open-ended responses revealed male and female inmates have different strategies for avoiding victimization, many of which can be linked back to tenets of the inmate code. Based on these findings it is suggested that gender responsive education and treatment are necessary to preventing and responding to fear about, and incidents of, sexual victimization in prisons.

\section{Introduction}

The prevalence of sexual victimization continues to be an issue among male and female inmates in the United States, with reported allegations of sexual victimization in 2015 almost tripling the number of allegations reported by correctional administrators in 2011 (Rantala, 2018). Although allegations have increased, not all inmates experience or think about sexual victimization in the same way. Some researchers have even found that inmates perceive prison rape to be a problem found mostly, if not only, among male inmates (Bradley \& Davino, 2002; Owen, 1998) despite the fact that women inmates have higher reported rates of victimization (Beck, Berzof sky, Caspar, \& Krebs, 2013; CaravacaSánchez, \& Wolff, 2016).

In studying adaptation to the prison environment, including the existence of an inmate culture, researchers started to document the existence of the inmate code as well as its function, processes, and methods of enforcement within male prison facilities (Clemmer, 1940; Hassine, 2011; Irwin \& Cressey, 1962; Sykes \& Messinger, 1960; Trammell, 2011; Wooden \& Parker, 1982). The inmate code is an informal guide to prison behavior (Clemmer, 1940; Cooley, 1992; Copes, Higgins, Tewksbury, \& Dabney, 2011; Sykes \& Messinger, 1960). This code is determined by the aggressive and dominant groups in the inmate hierarchy (Wooden \& Parker, 1982) and is constructed of norms which run counter to penal institutions' goals of rehabilitation (Hassine, 2011; Kalinich, 1980; Trammell, 2012). Among the most frequently cited tenets of the inmate code are: do your own time, steer clear of the prison economy (i.e. do not gamble, borrow, or lend), do not rat on a con, do not trust anyone, be tough, show respect, do not exploit other inmates (i.e. do not steal), and do not mess with drugs or homosexuals (Clemmer, 1940; Cooley, 1992; Copes et al., 2011; Hassine, 2011; Sykes \& Messinger, 1960). Within the inmate culture, if inmates follow this code of conduct, they are less likely to encounter trouble with other inmates while serving their sentence. 
Previous research has found that many female prisoners feel prisons are safer than their lives on the streets (Bradley \& Davino, 2002; Owen, 1998). This paradox pointed out by Owen (1998) and Edgar, O'Donnell, and Martin (2003), makes sense when considering the downward spiral in a woman's life that may eventually lead her to prison. Most women in penal institutions have already experienced a myriad of interpersonal abuse before being incarcerated (Batchelor, 2005). Women are often in need of trauma-informed services due to an assessed and reported history of emotional, physical and sexual abuse, mental health issues, and substance abuse (Bloom, Owen, \& Covington, 2003; Messina \& Grella, 2006). Therefore, they may associate incarceration as taking a "vacation," getting off the streets, away from abusive relationships and economic anxiety (Kruttschnitt, Carbone-Lopez, \& Macmillan, 2000; Owen, 1998, p. 40). However, Covington and Bloom (1998) suggest that women, by and large, continue to experience abuse in prison. According to Human Rights Watch (1996), incarcerated women are subjected to various degrees of physical, verbal, and sexual assault.

As will be discussed, men and women in prison experience violence and abuse to varying degrees. These experiences are dealt with in the context of their gendered prison experiences. The purpose of this study is to better understand the strategies used by incarcerated individuals to avoid situations that they perceive put them at higher risk for sexual victimization while incarcerated. Additionally, it is our purpose to understand how gender impacts perceptions of individual safety from sexual violence in prison.

\section{Literature Review}

\section{Sexual victimization and the prison experience}

Lockwood (1983) was one of the earliest researchers who argued that forcible rape in prisons was rare. The author based his claims on surveys published in the early 1980s which suggested that less than $1 \%$ of two cohorts of incarcerated men (N1=330; N2=76) were sexually assaulted (Lockwood, 1983; Nacci \& Kane, 1984). Although myths about rape are common, researchers have found that sexual violence in men's and women's prisons is reported by inmates to be part of the prison experience (Blackburn, Mullings, \& Marquart, 2008; Fleisher \& Krienert, 2009; Fowler, Blackburn, Marquart, \& Mullings, 2010).

Periodic reassessments of data further illustrates the reality of in prison sexual assault. StruckmanJohnson, Struckman-Johnson, Rucker, Bumby, and Donaldson (1996) initially concluded that 7\% of females and $22 \%$ of males experienced sexual violence in prison. Reassessing these data a few years later, the authors found that $19 \%$ of female offenders were sexually abused while incarcerated (Struckman-Johnson \& Struckman-Johnson, 2002). While the discrepancy in reported rates of female victimization can be partially attributed to the different definitions of rape employed in each study (Jones \& Pratt, 2008), it can also be explained by an individual inmate's definition of sexual assault and 
their level of awareness of the problem in prison. Worley, Worley, and Mullings (2010) examined prison rape awareness levels of incarcerated men and women in high-security prisons and found that women had a lower awareness of prison rape than men. These authors hypothesized that women may possess lower levels of rape awareness because they are more interested in forming familial communities, as opposed to focusing on power and status.

\section{Sexual coercion and violence}

It is important to highlight how sexual violence varies among male and female inmates. In male prisons, researchers have described a grooming process of new inmates that often begins with observation (Chonco, 1989; Wooden \& Parker, 1982). At this stage, offenders pay other inmates to watch and shadow newcomers and to gather information about their background. Once a target has been chosen, "turners" (Chonco, 1989, p. 75) work at befriending the new inmate (Fagan, Wennerstrom, \& Miller, 1996). Knowles (1999) referred to the use of this specific seductive tactic as "soft sell" (p. 11) in comparison to "hard sell" (p. 11) for which an inmate may be immediately approached to fight or succumb to sexual violence (Knowles, 1999; Wooden \& Parker, 1982). The new inmate is then tested through offerings such as cigarettes, toiletries, and other commodities. At this stage, the aggressor determines whether to continue "squeeze[ing]" the target or to turn his attention elsewhere (Chonco, 1989, p. 76). Once an inmate is approached, he must fight to demonstrate courage in which case he will be able to ward off future sexual advances, or submit to the sexual coercion and violence (Chonco, 1989).

Differently, sexual victimization and coercion in women's prisons occurs most often in, and as a result of, involvement in what researchers have described as "the mix" (Alarid, 2000, p. 392; Giallombardo, 1966; Owen, 1998, p. 179). The mix, is an alluring social vortex which invites inmates to do "easy-time," while, either covertly or overtly, economically and emotionally exploiting them (Alaird, 2000; Giallombardo, 1966, p. 134). It is a most volatile environment, where most of the fighting, sexual activity, and drug use in a female prison takes place (Alarid, 2000; Owen, 1998). Outside of the mix scene, Fleisher and Kreinert's (2009) inmate respondents maintained optimistic attitudes about successfully avoiding victimization by creating "cultural forms of self-protection" (p. 188). These include "safe-zones," such as religious groups, social isolation (i.e. stay to yourself), and avoiding congames and the sexual scene (p. 188).

\section{The modern female inmate}

Previous studies concentrated on prison violence and gender reported low rates of victimization within female correctional settings. Some studies indicate that the prison culture in women's prisons may be changing in that female inmate behavior may be becoming more similar to that found in men's correctional facilities (Batchelor, 2005; Greer, 2000). Batchelor (2005) draws attention to a "new 
breed" of female violence perpetrated by young offenders entering the criminal justice system (p. 359). These female inmates have begun to place a high value on respect, something that is more reflective of the values analogous to the male inmate culture (Batchelor, 2001, 2005; Belknap, Hosinger, \& Dunn, 1997). Research indicates that the rate and association of violence to gain respect is growing among incarcerated female populations and may stem from their socioeconomic and racial marginalization (Batchelor, 2005; Bradley \& Davino, 2002; Covington \& Bloom, 1998; Owen, 1998). Similar to male inmates, toughness has also been found to be emphasized in the female inmate culture as a method to discourage sexual victimization (Smith \& Batiuk, 1989).

While violence remains relatively rare among female inmates, compared to their male counterparts, and confrontations are mostly avoided (Alarid, 2000), the modern female inmate is more likely to resort to violence in specific instances. For example, female inmates may use violence to regulate or punish those who offend the prison community or in retaliation as has been found among male inmates (Edgar, O’Donnell, \& Martin, 2003; McGuire, 2011; Trammell, 2011). Additionally, disrespect, homosexuality, unreciprocated love, and jealousy are predictors of violence in female facilities (George, 2014; McGuire, 2011).

\section{The inmate code and factors related to in prison victimization}

For decades, researchers have examined the existence, intrinsic rules, and the impact of the inmate code of conduct in the lives of prisoners (Edgar, O’Donnell, \& Martin, 2003; Grapendaal, 1990; Hassine, 2011; Sykes \& Messinger, 1960). Sykes and Messinger (1960) explained that group cohesion or solidarity are the most pronounced themes of the inmate code of conduct. The researchers further theorized that the greater number of inmates who adopted the inmate code correlated to higher levels of solidarity and fewer incidents of prison violence (Sykes \& Messinger, 1960).

The existence of an inmate code has not been prominent in all research on prison adaptation. Cooley (1992), in a study of five Canadian federal prisons, found that no such structured code existed according to the 117 inmates he interviewed. Instead, Cooley (1992) discovered a loose and informal system of social norms which do not promote inmate cohesion and do not necessarily reduce violence. Similarly, Hassine (2011) claimed the inmate code to be implausible, mythical, and fictitious. Grapendaal (1990), who studied Dutch prison culture, found no solidarity among inmates but noticed that exploitation was a part of prison life. Nonetheless, these researchers confirm that the observed rules, regardless of their rigidity or informality, can create a cohesive group (Sykes \& Messinger, 1960), and at the same time destroy stability (Cooley, 1992) which may lead to isolation among inmates (Edgar, O’Donnell, \& Martin, 2003).

Researchers who found evidence of the existence of an inmate code, however, have described that its enforcement happens through violent means with the goal of maintaining domination and control over 
different groups of inmates (Cooley, 1992; Trammell, 2012). Therefore, rejection of the inmate code, according to Copes et al. (2011), could lead to more incidents of inmate-on-inmate victimization. Wooden and Parker (1982) discovered that inmates who defy the inmate code provoke increased and heightened harassment from aggressive inmates who want weaker inmates to assume feminine roles. The inmate prison code demands that vulnerable inmates submit and conform to the status and behaviors dictated by the prison culture, such as adopting a submissive or feminized role.

\section{The underground prison economy}

Early accounts about the existence and operation of the underground prison market stem in part from Radford's (1945) study of the German prisoner-of-war (POW) camps during World War II after serving time in the Stalag VII-A POW camp. An economist by trade, Radford closely analyzed the economic interactions between his fellow prisoners. He observed that although all prisoners had access to the same amount of food rations and cigarettes, personal preferences moved the underground market and trades became part of the local economy. In prisons, inmates who have access to commissary can use their extra goods in various ways, including manipulating others, bartering for other goods or services, and paying for protection, among others. In addition, the underground prison economy is a system that facilitates the selling and trading of prohibited goods and services (Copes et al., 2011; Kalinich, 1980; Kalinich \& Stojkovic, 1985).

Institutions of total control, by their very nature, inflict deprivation upon prisoners (Sykes, 1958) and are inherently exploitative (Edgar, O'Donnell, \& Martin, 2003). Kalinich (1980) explained that inmates look for ways to diminish deprivations by developing systems that facilitate and regulate the steady flow of illicit services, contraband, and enhanced commodities (Booyens \& Bezuidenhout, 2014; Copes et al., 2011). The underground prison market is also a vital aspect of informal social control and a considerable amount of an inmate's time is committed to satisfying its supply and demand (Hassine, 2011; Kalinich \& Stojkovic, 1985; Trammell, 2012).

Participation in the prison economy carries the benefit of solidifying an inmate's status and thereby enhancing the power and dominance the inmate can exert upon other inmates (Copes et al., 2011). The underground prison economy, however, can potentially put inmates at risk (Edgar, O’Donnell, \& Martin, 2003; Kalinich, 1980) as targets for violence (Kalinich \& Stojkovic, 1985). Those inmates not having enough money to buy commissary are more likely to be perceived as lower in the socioeconomic chain, weak, and likely to borrow leading to indebtedness. Similarly, inmates who loaned money and garnered debt, or did not have enough money to buy goods, have been found to be at greater risk of becoming victims of violence (Copes et al., 2011). This is because loaning money alerts other inmates that one possesses and has access to economic resources. These inmates also tend to stockpile which can attract unwanted attention. 


\section{Gang involvement}

Nothing upsets the prison environment more than lack of certainty and stability (Wilson, 2014). Group violence tends to erupt when inmates are unable to adapt to prison conditions (Kalinich \& Stojkovic, 1985). DeLisi (2004) and Beare and Hogg (2013) suggest that gang affiliation is the strongest threat to prison order. Facilities around the country utilize the term "security threat group" to refer to such criminally oriented entities in the prison system (Kristine, 2011). Prison gang affiliation occurs along racial and ethnic lines. The use of violence can lead to a higher status and prestige for an offender within a prison gang.

Contrary to the idea that gangs are a threat to prison life, Skarbek (2014) found gangs to be an intricate system of sophisticated entrepreneurial organizations which create order, not anarchy. Trammell (2012) further explored the order-maintenance goal of prison gangs. Although highly militarized and organized, gangs are highly motivated to live harmoniously with other gangs to avoid total lockdown or disruptions to their social and economic transactions. They are also incentivized to avoid fighting due to the unwanted attention it brings from the prison staff.

Most of the violence inflicted by prison gangs has been found to stem from the failure to settle a drug debt or for snitching (Richters et al., 2012; Wilson, 2014). Snitches (Cooley, 1992), child molesters, and drive-by shooters (Trammell, 2012) are considered by gangs to be the worst kind of offenders. In Trammell's (2012) study of prison violence, gang members, independent of race, thought it their mission to "take out" "dirty inmates" (p. 113) to keep children safe and protect communities. This method assured that gangs kept each other in check and maintained a united front against institutional controls (Trammell, 2012).

The proliferation of gangs in male prisons began to surface, showing more defined organizational contours and ingenuity, in the 1980s when the long-established order of social control (Skarbek, 2014) and the inmate code gave way to "social threat groups" (Hassine, 2011; Kalinich \& Stojkovic, 1985; Wood, Alleyne, Mozova, \& Mark, 2014). However, Wilson (2014) noted that as early as the 1950s the penal system underwent a transformation due to the exploding prison population (Hassine, 2011), the building of massive architectural penal institutions (Irwin, 1980; Knowles, 1999), and the growing racial and ethnic heterogeneity of inmates (Wood et al., 2014). These, compounded by the psychological imbalance of the average prisoner (Berg \& DeLisi, 2006), gave rise to a new type of inmate (Hassine, 2011; Kalinich \& Stojkovic, 1985; Wilson, 2014). Hassine (2011) explained how these "young bucks" kicked against the established order and refused the advice of the "old heads" (pp. 35-36). McCorkle (1992) found that younger inmates tended to resort to aggressive tactics to ward off attacks as opposed to the older inmates who had been accustomed to relying on avoidance mechanisms. Moreover, high levels of prison unemployment and older inmates' need for protection against younger inmates also contributed to the surge of gang formation (Hassine, 2011). 
The literature concerning gang presence and activity as an organized method of control and stability has characterized the exception, not the norm, in women's prisons (Greer, 2000; Harer \& Langan, 2001; Owen, 1998). Although similarly relying on group mechanisms to maintain social control, research has found that incarcerated women are more likely to create small pseudofamilies than larger gang-type groups (Kristine, 2011). Kristine (2011) further highlights that violence is unlikely to result even following conflicts or disputes between each pseudofamily. In contrast to male prison gangs, racial and ethnic boundaries are crossed by female inmates who participate in prison families and also those involved in same-sex relationships. While these groups may look different between male and female inmates, in female prisons, these family structural arrangements provide the vulnerable inmate protection and means of survival, in much the same way as gangs do on the streets and in male prisons (Owen, 1998).

In a recent qualitative study with females incarcerated in California, Kolb and Palys (2018) further validate the concept of pseudofamilies. Although reasons for joining a pseudofamily while incarcerated varied from one respondent to the other, female offenders reported that being part of a pseudofamily increased their sense of belonging and provided them with certain protections. First and foremost, pseudofamilies provided women emotional and social support. Additionally, it provided a safe space for nonfeminine female inmates to be part of a group without being discriminated against, as they filled the masculine roles of the "father" and/or "head of the family." Protection against violence was similarly cited as one of the benefits of joining a pseudofamily. Members of the same pseudofamily are expected to protect and defend one another either through violent means or through more diplomatic means of conflict resolution. While gangs and pseudofamilies differ considerably in their nature, both have been found to provide inmates with a safe space and protection against victimization.

\section{Inmates and religion}

Clemmer (1940) recognized, among the inmates he interviewed, that the least degree of prisonization was found among inmates who had adopted religion. He claimed that, although every inmate is subject to being prisonized by the exertion of "universal factors" (p. 300) upon entering the prison system, such as being assigned an inmate number and a prison uniform, religion itself prevented further prisonization. Religion inhibits prisonization insofar as the inmate does not claim affiliations inside the prison such as gang membership, does not accept the inmate code, spends time with like-minded individuals, and does not involve himself in homosexuality and gambling, but works and participates in allowed recreational activities. Thomas and Zaitzow (2006) mentioned that religious membership, like gangs, can provide safety and protection from theft and physical assaults. Listwan and colleagues (2014) found that the social support provided by religious groups, as opposed to mere participation in religious activities, is more effective at preventing poly-victimization in prison. 


\section{Loyalty among inmates}

McGuire (2011) found that inmates were intolerant of snitching against other inmates, with transgressors being severely punished even among incarcerated females. For instance, as punishments for being disloyal, an inmate suffering from cirrhosis sustained multiple kicks to her liver for snitching, another inmate was beaten on the head by a mob of women hurling padlocks inside socks, and another inmate was gang-raped and vaginally penetrated with foreign objects. Also, inmates attributed victimization to a failure to navigate and adhere to the norms concerning the prison economy, such as stealing from other prisoners. Other causes of violence included not settling drug debts and borrowing, "messing with someone's time" or being nosey (p. 153), and not keeping up with one's personal hygiene or neglecting to maintain neat and orderly surroundings.

The tenets of the inmate code described above can be found to certain degrees among both male and female inmates. Whether, loyalty or gang affiliation, participation in the underground prison economy, or finding religion, the way inmates do their time can put them more or less at risk for in-prison victimization. The current study examines how inmate's perceptions of what keeps them safe from harm correspond to aspects of the inmate code. Specifically, we examined gendered perspectives of the prison experience and how best to avoid victimization while incarcerated.

\section{Data and Methods}

\section{Data collection}

Open-ended responses analyzed for the present study were collected through self-administered questionnaires completed by a sample of male $(n=436)$ and female $(n=499)$ inmates in a large Southern prison system. All survey administrations were conducted in 2005-2006 by the research team. Sampling of units was based on the number of reported incidents of sexual assault occurring in the unit between 2003 and 2004 as well as the unit's proximity to the research team. Male inmates were randomly sampled with the help of correctional administrators from the general population only. Female inmates were sampled using simple random and systematic sampling techniques across all security levels (minimum, medium, and maximum) although the majority of female inmate respondents were also from the general population.

Once sampled, inmates were brought to the survey administration area where the research was explained to them by the research team and written consent was obtained from participating inmates. Those inmates who chose not to participate were returned to their regularly scheduled activities. Surveys were made available in both English and Spanish and the research team stayed in the administration area to answer any questions and to assist with literacy issues. Correctional staff were only present outside of the administration area. It took most respondents no longer than an hour to complete the questionnaire. Once completed, questionnaires were handled only by the research team. 
Table 1 presents the demographic characteristics of the inmates who completed the questionnaire. The majority of study participants reported being non-white (66.9\%) and had completed high school (66.3\%). The majority of study participants also identified as heterosexual (79.3\%) and being married (59.3\%).

Table 1. Sample descriptives $(n=935)$

\begin{tabular}{|c|c|}
\hline General characteristics & Mean or percentage \\
\hline Age (years) & 40.53 \\
\hline Sentence length (months) & 257.23 \\
\hline Time served (years) & 8.04 \\
\hline Time remaining (months) & 164.19 \\
\hline \multicolumn{2}{|l|}{ Gender } \\
\hline Male & $53.4 \%$ \\
\hline Female & $46.6 \%$ \\
\hline \multicolumn{2}{|l|}{ Race } \\
\hline White & $36.1 \%$ \\
\hline Not white & $63.9 \%$ \\
\hline \multicolumn{2}{|l|}{ Education } \\
\hline High school graduate & $66.3 \%$ \\
\hline Non-high school graduate & $32.8 \%$ \\
\hline \multicolumn{2}{|l|}{ Marital status } \\
\hline Single, never married & $40.7 \%$ \\
\hline Not single, married before & $59.3 \%$ \\
\hline Sexual orientation & \\
\hline
\end{tabular}




\begin{tabular}{|l|l|}
\hline Heterosexual & $79.3 \%$ \\
\hline Not heterosexual & $20.7 \%$ \\
\hline Prior incarceration & \\
\hline Yes & $43.2 \%$ \\
\hline No & $56.1 \%$ \\
\hline Current house type & \\
\hline Not cell (dorm) & $63.1 \%$ \\
\hline Cell & $33.5 \%$ \\
\hline
\end{tabular}

\section{Survey instrument}

The survey instrument used in this study collected information about various topics including correctional programming, inmate health, and perceptions of and experiences with victimization. Of importance to the present study are the strategies inmates suggest to avoid becoming a victim of sexual assault while incarcerated. The survey item analyzed asked the respondents the following, "Imagine you are giving advice to your best friend who is an inmate. What things would you tell your friend to successfully avoid being sexually assaulted?" This was an open-ended question that allowed participants to write in their responses in the space provided on the survey. For purposes of the survey, sexual assault was defined as "nonconsensual contact between the penis and vulva, penis and anus, the mouth and penis, mouth and vulva, or mouth and anus," and abusive sexual contact was defined as "intentional touching, either directly or through the clothing, of the genitalia, anus, groin, breast, inner thigh, or buttocks of any person without his or her consent." Inmate responses were content analyzed and grouped into themes. A random sample of the responses were analyzed by a second coder for interrater reliability resulting in an alpha of .807, suggesting a strong value of agreement between the two blind coders (Krippendorff, 2004).

\section{Findings}

Thematic analysis revealed that male and female inmates are similar in the advice and strategies they would suggest to avoid in prison sexual victimization. However, the suggested use of these strategies varied considerably. Themes developed from the male and female inmate responses included: (a) do your own time; (b) extortion; (c) sexuality; (d) respect/toughness; (e) religion; (f) trouble/gangs; (g) vigilance; and (h) report. 
While both male and female inmates suggested doing your own time to avoid in prison sexual victimization, research leads us to believe that male inmates are more likely to keep their distance from others and only associate with large groups of people often organized by race (i.e. gangs) (Greer, 2000; Harer \& Langan, 2001; Owen, 1998). Our study, however, suggests that female inmates (40.4\%) were more likely than male inmates $(7.5 \%)$ to suggest doing your own time. This finding is opposite to that of past literature which speaks to female inmate kinship networks, pseudofamilies, and the like. Females were more likely to advise their fellow inmates to stay to yourself, keep your distance, don't trust anyone, stay out of other's business, and, related to that, don't be "messy."

First and foremost, you have no real friends, never forget that. Stay to yourself, in your cubicle or cell. Avoid the dayroom. Beware of people who are overly friendly. Be cautious of your surroundings. Don't talk about personal things with other inmates or officers. If you feel threatened go to a ranking officer ASAP. (Female respondent)

Extortion was another prevalent theme among male (21.0\%) and female (19.2\%) inmate responses. Male inmates suggested their friends avoid accumulating debt, gambling, borrowing, accepting gifts and favors, paying for physical protection, and sharing personal information. Female inmates were similar in their advice, suggesting that their friend should not be co-dependent, share personal information, buy or give stuff to others, or get into debt. Females also noted that their friend should not buy a large amount of commissary because they will be targeted by those who realize the inmate has money. This exemplifies the inmate cultural belief that predators can use pretext to lure victims into a situation such that when victims run afoul of informal rules, sex can be exacted as remediation or payment (Fleisher \& Krienert, 2009).

As expected, the theme sexuality was also found among both male (21.0\%) and female (48.5\%) responses. Of all strategies revealed, advice related to sexuality was the most prevalent among female inmate responses. There was a difference, however, in the way that this theme was interpreted by male and female inmates. Often, female advice focused on clothing and behavior. Many inmates suggested that their friend wear baggy clothes, not be too friendly, not allow other inmates to touch or to see them naked, and not allow other inmates to get on their bunks.

I would tell my best friend to ware very loose-fitting clothes nothing too tight or inviting or appealing to the sex offender or any tempted offenders' eye. (Female respondent)

Related, many female responses centered on modesty. It was often suggested that women should "act like a lady." In regards to sexual relationships, female inmates suggested not flirting or misleading others, not getting involved in homosexual relationships, not being promiscuous, not getting "caught up in the games," and staying around other inmates who are straight. 
Male inmates also suggested rejecting sexual invitations, avoiding associating with inmates involved in homosexual activities, and avoiding participating in "come on" or sex games.

What I do is never put myself in situation or company of people whom openly or on the sly engage in homosexual activity. Let it be known right off that you are not down with homosexual lifestyle. And you do not play the come-on game in no ways. (Male respondent)

The theme respect/toughness was most prevalent among male inmates (42.4\%) but also found in a third (31.9\%) of female inmate responses. Male inmates suggested being physically strong and not acting "weak." They additionally suggested carrying oneself like a man, standing up for oneself, and fighting if necessary.

Conduct yourself with integrity. Learn the potential hot spots or troublesome areas and be on your toes. Most of all, be a man. If you won't fight, or if you snitch, you will lose any respect anyone might have for you and that will result in your becoming prey for others. (Male respondent)

Male inmates noted staying physically fit, getting a tattoo, and holding your gaze as ways to show toughness.

I would tell a friend to just mind his own business, stay fit and ready to protect yourself at all cost. Never ask people for their personal belongings or favors for which they can exact a payment of sex. Carry yourself in a manner that does not seem weak. (Male respondent)

Toughness was also a theme present among female inmates with suggestions such as not letting anyone manipulate you, just "saying no," standing up for yourself, and setting boundaries. Female inmates also recommended using verbal threats and fighting back. One inmate even suggested "keep[ing] a lock in your sock at night" in case there is an assault attempt while sleeping.

Analysis of female inmate responses also revealed that respect is a prevalent theme. Female inmates suggested both treating others with respect and practicing self-respect. They recommended being confident and not letting other inmates know you are intimidated. One female inmate noted, "it's how you carry yourself" that will keep you from being victimized.

I would advise my (Bunkie) or new inmate, "Rare that you find best friend in prison" do not tell anyone, bragging or casually how much money you have! Don't give the impression that you are easily influenced, impressed, intimidated, or scared. Always watch to see who's watching you. Especially if your new, young, and this is your first time. Predators feed on fear over friendliness. (Female respondent) 
As has been found in previous literature (Thomas \& Zaitzow, 2006; Wooden \& Parker, 1982), religion seems to be perceived by some inmates as a protective factor. Male inmates (5.2\%) recommended associating with spiritual/religious inmates, believing and behaving according to religious teachings, and engaging in spiritual/religious activities. One male inmate suggested using the prison experience as a theological journey:

To avoid any contact physically would to allow your belief in the religion of your walk with God be known. Christ needs to be evident in your life because God is everywhere you go. And the faith that you are claiming needs to be of the truth of God's word that is living and not something treated as though $\mathrm{He}$ is common. Trusting in him and not allowing the world to influence you in this journey. To me this journey has been the best theological school I could ever have enrolled in. In order to know the truth so that I could be free and maintain a normal life without being locked up within. (Male respondent)

Female inmates (8.7\%) also suggested turning to and getting involved in religious activities. One female inmate recommended that just "hanging around the Christian women" would serve to decrease the chance that one would be sexually victimized. Notice that for this inmate, participation in religious activities is not needed as long as others notice your proximity to religious-oriented individuals and services.

Thematic analysis of responses also revealed staying out of trouble and away from gang activities was recommended as an avoidance strategy for males (5.2\%) and females (14.3\%). While some male inmates suggested joining a gang for protection, others recommended avoiding gang membership and minimizing contact with gangs and gang members. Female inmates additionally suggested staying out of trouble and staying out of "the mix," corroborating Owen's findings (1998). Female inmates also recommended avoiding predators and younger inmates. This was an interesting finding as it has been found that younger inmates tend to be more violent and troublesome (Colby, Mears, \& Bales, 2015; George, 2014; Scott \& Steinberg, 2008).

Being aware of your surroundings, or practicing vigilance, was another common theme for male (18.3\%) and female (17.1\%) respondents. The vigilance-related responses can be further broken down into social vigilance and physical/location vigilance. For social vigilance, male inmates recommended observing people, exercising caution with associating and trusting others, and staying in sight of officers and other inmates:

The advice that I would give to mine best friend would be to just be carful with who he hangs around with, Plus don't trust anyone, for you don't know who may sexual assault you. (Male respondent) 
Nothing is free at the Big House, and you have no friends. Never take anything from anyone as a gift because your left in debt or owing! All offenders here are very deviant, most have advanced sexual hang-ups, so don't trust anyone because its all a game. Never be alone with someone you don't know. Most sexual deviants try to control, so never be controlled. Stay away from back rooms late at night, most predators hang around bathroom areas. Remember, the people here are social and sexual outcasts-Beware of them all. (Male respondent)

Regarding physical/location vigilance, male inmates suggested observing surroundings, having knowledge of trouble spots for sexual assault, never being naked, sleeping light, and avoiding certain places like the shower in certain circumstances.

Showers with those you know, keep you back to the wall and if you drop the soap, leave it. (Male respondent)

Female inmate advice centered more on social vigilance although one female inmate did recommend having a "friend watch out for you while you are in the shower." Most often, advice suggested by female inmates centered on not being alone, being observant/aware, choosing friends wisely, and "watching your back."

A place like this can't be trusted. No one is your friend, but yourself therefore trust only yourself. (Female respondent)

Choose your associations carefully, be guarded and observe people for a while first. Then still be very selective with who you trust. Do not get involved in other people's "dramas" or with people who are "messy"/negatively involved in other people's affairs/business. (Female respondent)

The final theme found among both male (17.0\%) and female (20.5\%) inmate responses was that of reporting. Male inmates suggested their friend report and notify authorities if they are approached in a sexual way or sexually assaulted.

If you get a cellmate that makes you uncomfortable or fearful, get a hold of an officer and ask to be moved immediately. If they won't listen ask to talk to rank, meaning a ranking officer. Be very cautious who you associate with in the day room and don't ever let another inmate talk you into going anywhere that you will be alone or unseen (for instance, at work, on rec yard or gym, or "come to my cell for a second"). No matter how friendly or trustworthy they seem. (Male respondent)

Female inmates also recommended telling a friend, telling correctional staff, or writing home to tell a family member. Moving away from the predator or out of the environment where the harassment 
and/or unwanted behavior occurred was additionally suggested. Some inmates went even further and suggested having written documentation concerning all incidents:

Stay away and avoid person who is bothering you, confront the person tell them to leave you alone. If that doesn't work go directly to the dorm officer and report the person and, if possible, make a written report with dates and what took place and what was said to you as documentation as proof. Don't act like a victim or you'll become a victim. (Female respondent)

\section{Gender-specific responses}

Our study revealed three gender-specific themes. First, a few female inmates denied that sexual victimization occurred in women's prison facilities. The theme of denial was found among $3.4 \%$ of female respondents. They were quick to point out that while prison rape occurs among male inmates, it does not happen in women's prisons, a general finding documented by Fleisher \& Krienert (2009).

I just wanted to state that any answers are from a female prisoner. Things are very different for us than from a male. I've been locked up a total of 14 years and 2 months. And I've seen and heard a lot, and I know that females are weaker of the flesh and more likely to consent to sex because of their needy nature. Sometimes they get mad at their lover and use that to hurt them, sometimes some females use sexual assaults that never happened to get moved around or something. With men, I do believe rape happens often so look more carefully into male rape. But females, focus on something else to help us. Thank you. (Female respondent)

None of this has happen on a female's unit to my knowledge and I been hear $101 / 2$ years. (Female respondent)

As for male inmates, two themes were present that were not found among female inmate responses. First, male inmates $(17.0 \%)$ suggested that others should not snitch and should stay loyal to their fellow inmates. As male inmates perceive it, snitches are targets for sexual victimization. This is not a new concept as past literature has found that retaliation for going to authorities may involve sexual assault (McGuire, 2011).

First I would advise him that he had two choices, one he could go to those in charge (guards) or he can defend his self, and really defending his self will be a lot better because in prison you don't want to pick up a jacket as a snitch! Sometimes one has to defend himself to show the person who is trying to pull these kinds of games on you that you aren't some weak person, and if you don't fight then others will prey on him. (Male respondent)

Responses also revealed that some male inmates (1.3\%) believe that associating with members of your own race while avoiding members of other races can keep one from becoming the victim of prison 
sexual assault.

You must avoid associating with other races. Prison breeds racial hatred. (Male respondent)

If you go outside your race to mingle you set yourself off from your own race. (Male respondent)

\section{Discussion}

Rates of rape and sexual assault are known to be notoriously underrepresented in U.S. prisons (Hassine, 2011; Richters et al., 2012; Struckman-Johnson \& Struckman-Johnson, 2000). Nationally, inmate surveys of prison sexual victimization place the victimization rate at $4 \%$ in prisons (Beck et al., 2013). Among the reasons known to discourage reporting to the authorities are the grey areas pertaining to the definition of sexual assault (Tjaden \& Thoennes, 2006; Trammell, 2012), fear of shame and retaliation (Tewskbury, Connor, \& Denney, 2014; Struckman-Johnson et al., 1996; Trammell, 2012), and fear of being labeled as homosexual or as a snitch (Human Rights Watch, 2001).

The results of the current study support previous research findings which have consistently reported the protective effect of staying away from, and also being vigilant of, gangs and "trouble groups" (Cooley, 1992; Richters et al., 2012; Wilson, 2014), being careful with your money and possessions (Edgar, O’Donnell, \& Martin, 2003; Kalinich, 1980; Kalinich \& Stojkovic, 1985), and congregating with prosocial peers while institutionalized (Clemmer, 1940; Thomas \& Zaitzow, 2006). For women inmates this would involve staying out of "the mix" as described by Owen (1998).

Findings unique to the present study were that women were more likely than men to advise their fellow inmates to do their own time and not to engage with other inmates. Because women have more likely been found to form small family-like units inside the prison environment (Jiang \& Winfree, 2006) that provide "safe zones" within which inmates can survive while incarcerated (Fleisher \& Krienert, 2009), a higher prevalence of advising another inmate to "do your time" was expected among male offenders.

It is important to keep in mind, however, that a growing body of research has described a change among women inmates whose behaviors are not consistent with what has been previously documented (Batchelor, 2005; Greer, 2000; Harer \& Langan, 2001). Young female offenders entering the criminal justice system more recently are slowly changing the once predictable female correctional environment. Young offenders' inclination to uphold values such as respect and toughness (Batchelor, 2001, 2005; Belknap, Hosinger, \& Dunn, 1997) have created an environment where violence is no longer the last resort to resolve conflicts (Edgar, O’Donnell, \& Martin, 2003; Trammell, 2011; McGuire, 2011). The modern female inmate, therefore, resembles behaviors and characteristics once thought to be confined to male inmates, which may explain the findings of this research. 
The results from our research additionally suggest that men and women avoid victimization in different ways. Gender-specific responses focused on the themes of: (a) denial; (b) loyalty; and (c) race. Denial among female inmates is problematic in that, if a female inmate doesn't believe sexual victimization occurs, she may be victimized or indicate to others (as done in this study) that all female inmates are safe from the threat of sexual victimization because it does not happen in female prisons as reported by Fleisher and Krienert (2009).

The lack of loyalty, most often exemplified by the role of snitch, was a focus of male inmates. Loyalty is a long-recognized component of the inmate code and it seems to still be important to a male inmate's perception of safety. The second theme specific to male inmates was race. As was discussed in the literature review, empirical studies have indicated the prevalence of race-based gangs and how this social structure is used for protection in male prisons (Wood et al., 2014). This is likely why some male respondents focused on race when advising another inmate on how best to protect themselves.

The findings of this study identify areas of importance for correctional administrators looking to develop policy and practices to respond to sexual violence within their facilities. While inmate perceptions of their environment are useful, it is important to remember that the suggestions provided in this study come from inmates who may have been impacted by prison myths surrounding sexual victimization such as those identified by Fleisher and Krienert (2009). Therefore, inmate responses should not be the only source relied upon when making decisions about prison safety. However, inmate responses in this study do point to areas where inmates may more readily accept some administrative practices or prevention strategies and describe attitudes that may prevent or complicate the adoption of others. Programming can be used to educate inmates about coercion and debt. In addition, reporting mechanisms considered safe by inmates could be put into place so that if an inmate is at risk or knows of another inmate at risk, they can report this to correctional staff. Although, for this to happen, they would have to overcome the "do your own time" aspect of prison life. If inmates are unwilling to help other inmates, it may leave already vulnerable inmates at risk. Correctional administrators could also use this study as a jumping off point for peer education programs where inmates are willing to educate and assist each other, especially about risky behaviors, as long as programs are monitored for the presence myth acceptance and sharing. Ultimately, if inmates are aware of the behaviors that put them more at risk, they may be more successful at avoiding sexual victimization.

It is important to note the limitations of the current study. The findings presented here are based on a cross-sectional study using self-report surveys of prison inmates. Additionally, as this sample of male and female inmates were drawn from one state prison system and true representation is unknown, findings cannot be generalized back to the larger population within the same prison system or inmates in other prison systems. There is also the issue of defining sexual assault. Even when presented with 
definitions of sexual assault on the survey, it is possible that preconceived notions of sexual assault impacted participant responses. This often happens due to the socialization process in which inmates become familiar with prison culture and its own code of definitions and regulations. As an example, Fleisher and Kreinert (2009) point out that same-sex relationships and the definition of rape are often conceptualized different inside and outside the prison environment.

The scope of sexual victimization in the prison context continues to be an important avenue for future research to better understand how to effectively respond to the problem of prison sexual violence and increase prisoner safety. Consequently, there are many avenues for future research including more attention to the relationships between correctional staff and inmates and how these relationships impact the prisoner experience. It is similarly important that future research focuses on genderspecific perceptions and experiences within the prison environment as previous research has described not only gender-specific needs among inmates but also gender-specific contexts within which these inmates exist. One major gap in the existing literature of prison violence is the role of religiosity and/or spirituality among female inmates. As some evidence suggests that those affiliated with a religious group are less likely to be victimized while incarcerated, gender-specific research in this area could lead to better understanding of the role religiosity and/or spirituality may play among female inmates. Understanding who is most vulnerable to sexual exploitation and assault and what can be done to decrease risk for victimization can lead to improved communication and accountability which, in turn, may lead to the establishment of safer environments for male and female inmates to serve their time.

\section{References}

Alarid, L. (2000). Sexual assault and coercion among incarcerated women prisoners: Excerpts from prison letters. Prison Journal, 80(4), 391-406.

Batchelor, S. A. (2001). The myth of girl gangs. Criminal Justice Matters, 43(1), 26-27.

Batchelor, S. A. (2005). 'Prove me the bam!' Victimization and agency in the lives of young women who commit violent offences. Probation Journal, 52 (4), 358-375.

Beare, M., \& Hogg, C. (2013). Listening in ... to gang culture. Canadian Journal of Criminology and Criminal Justice, 55(3), 421-452.

Beck, A., Berzofsky, M., Caspar, R., \& Krebs, C. (2013). Sexual victimization in prisons and jails reported by inmates, 2011-12 (NCJ 241399). Retrieved from https://www.bjs.gov/content/pub/pdf/svpjrill12.pdf

Belknap, J., Holsinger, K., \& Dunn, M. (1997). Understanding incarcerated girls: The results of a focus group study. Prison Journal, 77(4), 381-404. 
Berg, M., \& DeLisi, M. (2006). The correctional melting pot: Race, ethnicity, citizenship, and prison violence. Journal of Criminal Justice, 34, 631-642.

Blackburn, A. G., Mullings, J. L., \& Marquart, J. W. (2008). Sexual assault in prison and beyond: Toward an understanding of lifetime sexual assault among incarcerated women. Prison Journal, 88(3), 351-377.

Bloom, B., Owen, B., \& Covington, S. (2003). Gender-responsive strategies research, practice, and guiding principles for women offenders (NIC Accession Number 018017). Retrieved from https://nicic.gov/genderresponsive-strategies-research-practice-and-guiding-principles-women-offenders

Booyens, K., \& Bezuidenhout, C. (2014). An exploratory study of sex and rape behind bars in a South African prison. International Criminal Justice Review, 24(4), 377-391.

Bradley, R., \& Davino, K. (2002). Women's perceptions of the prison environment: When prison is "the safest place I've ever been." Psychology of Women Quarterly, 26(4), 351-359.

Caravaca-Sánchez, F., \& Wolff, N. (2016). Self-report rates of physical and sexual violence among Spanish inmates by mental illness and gender. The Journal of Forensic Psychiatry and Psychology, 27(3), 116.

Chesney-Lind, M., \& Eliason, M. (2006). From invisible to incorrigible: The demonization of marginalized women and girls. Crime Media Culture, 2(1), 29-47.

Chonco, N. (1989). Sexual assaults among male inmates: A descriptive study. Prison Journal, 69(1), 72-82.

Clear, T., Hardyman, P., Stout, B., Lucken, K., \& Dammer, H. (2000). The value of religion in prison. Journal of Contemporary Criminal Justice, 16(1), 53-74.

Clemmer, D. (1940). The prison community. New York: Holt, Rinehart \& Winston.

Cooley, D. (1992). Prison victimization and the informal rules of social control. Forum on Corrections Research, 4(3), 31-36.

Colby, V., Mears, D., \& Bales, W. (2015). Unpacking the relationship between age and prison misconduct. Journal of Criminal Justice, 43(5), 418-427.

Copes, H., Higgins, G. E., Tewksbury, R., \& Dabney, D. (2011). Participation in the prison economy and likelihood of physical victimization. Victims $\mathcal{E}$ Offenders, 6(1), 1-18.

Covington, S., \& Bloom, B. (1998, November). Gender-specific programming for female offenders: what is it and why is it important? Paper presented at the Annual Meeting of the American Society of Criminology. Retrieved from https://www.stephaniecovington.com/assets/files/13.pdf 
DeLisi, M. (2004). Criminal careers behind bars. Behavioral Sciences and the Law, 21, 653-669.

Dumond, R. (2003). Confronting America's most ignored crime problem: The Prison Rape Elimination Act of 2003. The Journal of the American Academy of Psychiatry and the Law, 31, 354-360.

Edgar, K., O'Donnell, I., \& Martin. C. (2003). Prison violence: The dynamics of conflict, fear and power. Portland, OR: Willan Publishing.

Fagan, T. J., Wennerstron, D., \& Miller, J. (1996). Sexual assault of male inmates: Prevention, identification, and intervention. Journal of Correctional Health Care, 3(1), 49-65.

Fleisher, M. S., \& Krienert, J. L. (2009). The myth of prison rape: Sexual culture in American prisons. New York: Rowman \& Littlefield Publishers, INC.

Fowler, S. K., Blackburn, A. G., Marquart, J., \& Mullings, J. L. (2010). Would they officially report an inprison sexual assault? An examination of inmate perceptions. Prison Journal, 90(2), 220-243.

George, E. (2014). A woman doing life: Notes from a prison for women (2 ${ }^{\text {nd }}$ ed.). Oxford, NY: Oxford University Press.

Grapendaal, M. (1990). The inmate subculture in Dutch prisons. The British Journal of Criminology, 30(3), 341-357.

Greer, K. (2000). The changing nature of interpersonal relationships in a women's prison. Prison Journal, 80(4), 442-468.

Giallombardo, R. (1966). Society of women: A study of a women's prison. New York: Wiley.

Harer, M., \& Langan, N. (2001). Gender differences in predictors of prison violence: Assessing the predictive validity of a risk classification system. Crime and Delinquency, 47(4), 513-536.

Hassine, V. (2011). Life without parole: Living in prison today (5 ${ }^{\text {th }}$ ed.). Oxford, NY: Oxford University Press.

Human Rights Watch (2001). No escape: Male rape in U.S. prisons. New York: Author.

Human Rights Watch (1996). All too familiar: Sexual abuse of women in U.S. state prisons. Retrieved from https://www.hrw.org/reports/1996/Us1.htm

Irwin, J. (1980). Prisons in turmoil. Boston: Little, Brown, \& Company.

Irwin J., \& Cressey D. (1962). Thieves, convicts and the inmate culture. Social Problems, 10(2), 145-147. 
Jiang, S., \& Winfree Jr., L. T. (2006). Social support, gender, and inmate adjustment to prison life: Insights from a national sample. Prison Journal, 86(1), 32-55.

Jones, T., \& Pratt, T. (2008). The prevalence of sexual violence in prison: The state of the knowledge base and implications for evidence-based correctional policy making. International Journal of Offender Therapy and Comparative Criminology, 52(3), 280-295.

Kalinich, D. (1980). Inmate economy. New York: Lexington Books.

Kalinich, D., \& Stojkovic, S. (1985). Contraband: The basis for legitimate power in a prison social system. Criminal Justice and Behavior, 12 (45), 435-451.

Kolb, A., \& Palys, T., (2018). Playing the part: Pseudofamilies, wives, and the politics of relationships in women's prisons in California. Prison Journal, 98(6), 678-699.

Krippendorff, K. (2004). Content analysis: An introduction to its methodology (2 ${ }^{\text {nd }}$ ed.). Thousand Oaks, CA: Sage.

Kristine, M. (2011). Gangs and violence in prison. In W. J. Chambliss (Ed.), Corrections (pp. 105-119). Thousand Oaks, CA: Sage.

Kruttschnitt, C., Carbone-Lopez, K., \& Macmillan, R. (2006). Patterns of intimate partner violence and their associations with physical health, psychological distress, and substance abuse. Public Health Reports, 121, 382-392.

Knowles, K. (1999). Male prison rape: A search for causation and prevention. The Howard Journal of Criminal Justice, 38(3), 267-282.

Listwan, S., Daigle, L., Hartman, J., \& Guastaferro, W. (2014). Poly-victimization risk in prison: The influence of individual and institutional factors. Journal of Interpersonal Violence, 29(13), 2458-2481.

Lockwood, D. (1983). Issues in prison sexual violence. Prison Journal, 63(1), 73-79.

McCorkle, R. (1992). Personal precautions to violence in prison. Criminal Justice \& Behavior, 19(2), 160173.

McGuire, D. (2011). Doing the life: An exploration of the connection between the inmate code and violence among female inmates. Journal of the Institute of Justice and International Studies, 11, 145-158.

Messina, N., \& Grella, C. (2006). Childhood trauma and women's health outcomes in a California prison population. American Journal of Public Health, 96(10), 1842-1848. 
Nacci, P. L., \& Kane, T. R. (1984). Sex and sexual aggression in federal prisons: Inmate involvement and employee impact. Federal Probation, 48, 46-53.

Owen, B. (1998). "In the mix": Struggle and survival in a women's prison. New York: State University of New York Press.

Radford, R. (1945). The economic organisation of a P.O.W. camp. Economica, 12 (48), 189-201.

Rantala, R.R. (2018). Sexual victimization reported by adult correctional authorities, 2012-15 (NCJ 251146). Retrieved from https://www.bjs.gov/content/pub/pdf/svraca1215.pdf

Richters, J., Butler, T., Schenider, K., Yap, L., Kirkwood, K., Grant, L., Richards, A., Smith, A., \& Donovan, B. (2012). Consensual sex between men and sexual violence in Australian prisons. Archives of Sexual Behavior, 41(2), 517-524.

Scott, E., \& Steinberg, L. (2008). Adolescent development and the regulation of youth crime. The Future of Children, 18(2), 15-33.

Skarbek, D. (2014). The social order of the underworld: How prison gangs govern the American penal system. Oxford, NY: Oxford University Press.

Smith, N., \& Batiuk, M. (1989). Sexual victimization and inmate social interaction. Prison Journal, 69(2), 29-38.

Struckman-Johnson, C., \& Struckman-Johnson, D. (2000). Sexual coercion rates in seven Midwestern prison facilities for men. Prison Journal, 80(4), 379-390.

Struckman-Johnson, C., \& Struckman-Johnson, D. (2002). Sexual coercion reported by women in three Midwestern prisons. Journal of Sex Research, 39(3), 217-227.

Struckman-Johnson, C., \& Struckman-Johnson, D. (2006). A comparison of sexual coercion experiences reported by men and women in prison. Journal of Interpersonal Violence, 21(12), 1591-1615.

Struckman-Johnson, C., \& Struckman-Johnson, D. (2013). Stopping prison rape: The evolution of standards recommended by PREA's National Prison Rape Elimination Commission. Prison Journal, 93(3) 335-354.

Struckman-Johnson, C., Struckman-Johnson, D., Rucker, L., Bumby, K., \& Donaldson, S. (1996). Sexual coercion reported by men and women in prison. The Journal of Sex Research, 33(1), 67-76.

Sykes, G. (1958). The society of captives. Princeton, NJ: Princeton University Press. 
Sykes, G., \& Messinger, S. (1960). The inmate social system. In R. A. Cloward, D. R. Cressey, G. H. Grosser, R. McCleery, L. E. Ohlin, G. M. Sykes, et al. (Eds.), Theoretical studies in social organization of the prison (pp. 5-19). New York: Social Science Research Council.

Tewksbury, R., Connor, D., \& Denney, A. (2014). Disciplinary infractions behind bars: An exploration of importation and deprivation theories. Criminal Justice Review, 39(2) 201-218.

Thomas, J., \& Zaitzow, B. (2006). Conning or conversion? The role of religion in prison coping. Prison Journal, 86(2), 242-259.

Trammell, R. (2011). Symbolic violence and prison wives: Gender roles and protective pairing in men's prisons. Prison Journal, 91(3) 305-324.

Trammell, R. (2012). Enforcing the convict code: Violence and prison culture. Boulder, CO: Lynne Rienner Publishers.

Tjaden, P., \& Thoennes, N. (2006). Extent, nature, and consequences of rape victimization: Findings from the National Violence Against Women survey (NCJ 181867). Retrieved from

https://www.ncjrs.gov/pdffiles1/nij/210346.pdf

Ward, D., \& Kasenbaum G. (1964). Homosexuality: A mode of adaptation in a prison for women. Social Problems, 12, 159-177.

Wilson, D. (2014). Pain and retribution: A short history of British prisons, 1066 to the present. London: Reaktion Books Ltd.

Wood, J., Alleyne, E., Mozova, K., \& Mark, J. (2014). Predicting involvement in prison gang activity: Street gang membership, social and psychological factors. Law and Human Behavior, 38(3), 203-211.

Wolff, N., Blitz, C., Shi, J., Bachman, R., \& Siegel, J. (2007). Sexual violence inside prisons: Rates of victimization. Journal of Urban Health, 83(5), 835-848.

Wooden, W. S., \& Parker, J. (1982). Men behind bars: Sexual exploitation in prison. New York: Plenum Press.

Worley, V., Worley, R., \& Mullings, J. (2010). Rape lore in correctional settings: Assessing inmates' awareness of sexual coercion in prison. Southwest Journal of Criminal Justice, 7(1), 65-86.

\section{Contributors}

Beatriz Amalfi Marques completed her Master of Science degree in Criminal Justice from the University of Houston - Downtown and is currently a doctoral student in the College of Criminal Justice 
at Sam Houston State University.

Ashley G. Blackburn, Ph.D. is a professor of criminal justice and currently serves as Chair of the Department of Criminal Justice and Social Work at the University of Houston - Downtown.

Shannon K. Fowler, Ph.D. is an associate professor of criminal justice in the Department of Criminal Justice and Social Work at the University of Houston - Downtown.

Janet L. Mullings, Ph.D. is a professor of criminal justice and currently serves as Associate Dean for Program Development in the College of Criminal Justice at Sam Houston State University.

Maria L. Lecuna completed her Bachelor of Science degree in Criminal Justice from the University of Houston - Downtown and is currently working toward her Master of Education in Teaching degree at the University of North Texas.

\section{Reviews}

